\title{
Changes in postpartum metabolites and resumption of ovarian cyclicity in primiparous and multiparous dairy cows
}

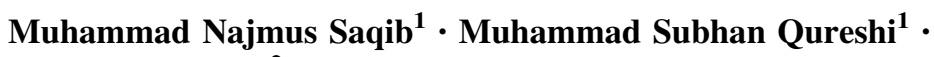 \\ Rifat Ullah Khan ${ }^{2}$
}

Received: 16 August 2017/Accepted: 15 November 2017/Published online: 12 January 2018

(C) The Korean Society for Applied Biological Chemistry 2018

\begin{abstract}
The postpartum period in high-yielding dairy cows creates an enormous drain of nutrients in favor of milk yield which antagonizes the resumption of ovulatory cycles. Therefore, a study was undertaken to evaluate the association of changes in postpartum serum metabolites with resumption of ovarian cyclicity. A total of 24 clinically healthy, freshly parturated primiparous (P-1) and multiparous (P-2) Holstein Frisian cows was selected. Cows were further divided on the basis of body condition score (BCS) 1 and 2 having BCS 3 or above 3, respectively. Weekly blood samples were collected and serum glucose, cholesterol, triglycerides, progesterone, and cortisol concentrations were determined for a period of 7 weeks. The glucose concentration was significantly $(P<0.05)$ higher in cows in $\mathrm{P}-2$ during week 7 . Cows in parity 2 had significantly $(P<0.05)$ high cholesterol during week 6 and 7 . The serum triglyceride concentration in multiparous animals having BCS-2 during week 6 was increased significantly $(P<0.05)$. Serum cortisol was significantly $(P<0.05)$ high in $\mathrm{P}-1$ during week 1 and 2 and significantly $(P<0.05)$ high in $\mathrm{P}-2$ during week 7 . Serum progesterone was significantly $(P<0.05)$ higher in cows during week 7 in P-2 having BCS-2. The increased serum progesterone concentration during postpartum period was associated with decreased levels of serum cortisol
\end{abstract}

Rifat Ullah Khan

rifatullahkhhat@gmail.com

1 Department of Livestock, Breeding and Genetics, Faculty of Animal Husbandry \& Veterinary Sciences, The University of Agriculture, Peshawar, Pakistan

2 Department of Animal Health, Faculty of Animal Husbandry \& Veterinary Sciences, The University of Agriculture, Peshawar, Pakistan and more availability of cholesterol and glucose. The multiparous cows maintained the postpartum blood metabolite concentration and showed better adaptability to reproductive cyclicity during the postpartum period as compared to primiparous cows.

Keywords Postpartum · Metabolism · Multiparous · Primiparous · Cows

\section{Introduction}

The high-yielding dairy cows are usually in negative energy balance (NEB) which results in greater physiological stress due to depressed appetite [1] and may badly impact the reproduction process [2]. In early lactation stage, the nutrient demand may increase and the body reserves are usually utilized which ultimately creates a great problem for reproduction, production, and general welfare in high-yielding dairy cows [3]. Delayed resumption of postpartum cyclicity (RPC) has been associated with severe NEB which ultimately negatively affects the postpartum metabolism and reproductive efficiency [4]. Cow fertility is directly related to health during the early postpartum period. Factors negatively influencing the resumption of cyclicity include drastic changes in body condition during the dry period and early postpartum, therefore, it is imperative for dairy producers to implement effective transition cow management program [1].

Blood metabolites are generally monitored to assess the risk of postpartum disorders. Serum progesterone concentration is a good indicator for the resumption of ovarian activity [5]. The corpus luteum activity is functionally considered when the progesterone concentration exceeds $1 \mathrm{ng} / \mathrm{dl}$ [6]. In addition to blood metabolites, body 
condition score (BCS) has been closely linked with the energy balance and risk of postpartum diseases [7]. Further, BCS may also impact NEB and RPC during the postpartum period in dairy cattle [8]. In some studies, the incidence of delay RPC was increased in cows having reduced BCS during the postpartum period $[8,9]$. On the other hand, Shin et al. [7] concluded that a higher BCS increased nonesterified fatty acids (NEFAs) and reduced glucose level, leading to the increased reproductive disorders and decreased productive performance during the postpartum period.

Postpartum dairy cows undergo marked changes in energy status proceeding the time they are returning to normal restoration of ovarian cycles [10]. Cows calving on a 365-day cycle are important to the sustainability of a cattle operation, but the relationship between cow body condition and the resumption of postpartum reproductive processes is poorly understood [11]. As demand for nutrients increases in the body, animals start losing their body weight and if proper feeding is not practiced, the animal goes into a state of nutritional deficiency leading to decreased milk production and delayed ovarian cycle [12]. The objective of the present study was to find the effect of BCS on the blood metabolites and resumption of ovarian cyclicity in primiparous and multiparous dairy cows.

\section{Materials and methods}

\section{Animal selection}

A total of 24 Holstein Frisian cows was selected and divided into primiparous (P-1) and multiparous (P-2). Cows were further divided into body condition score 1 (BCS up to 3) and 2 (BCS above 3). Cows were fed to meet the production requirement of NRC (1988).

\section{Blood sampling}

Weekly sampling was conducted from the day of parturition up to seventh weeks and the following parameters were determined. A $5 \mathrm{ml}$ blood sample was collected on schedule date from the jugular vein of each cow. The blood sample was put into a sterile vacutainer tube without anticoagulant and labeled. The collected blood samples were centrifuged at $3000 \mathrm{rpm}$ for $15 \mathrm{~min}$ and serum was decanted, labeled, and stored at $4{ }^{\circ} \mathrm{C}$ until analyzed. Serum progesterone $\left(\mathrm{P}_{4}\right)$ and cortisol concentrations were determined through commercially available ELISA kits (AccuBind Lake Forest, CA, USA). Similarly, blood triglycerides, glucose, and cholesterol were determined through spectrophotometer using commercially available kits (Biotech Reagent, Biotechnical Co. Ltd).

\section{Statistical analysis}

The experimental data obtained from postparturient dairy cows were subjected to the standard method of statistical analysis. The mean values and standard error of different parameters were compared using Duncan multiple test. Interaction between parity, BCS, and week was performed using general linear model (GLM) using SPSS windows version 16.0. The differences were considered statistically significant at $P<0.05$.

\section{Results}

The mean values of serum glucose concentration at different weeks after parturition are given in Table 1 . The table shows that parity, BCS, and postpartum intervals have a significant effect on serum glucose concentration $(P<0.05)$. The interaction effect of Parity $\times$ BCS $\times$ Week was found nonsignificant $(P>0.05)$. The glucose concentration was significantly higher in cows in P-2 during week 7.

The mean values of serum cholesterol concentration at different weeks after parturition are given in Table 2. The table showed that parity and postpartum intervals have a significant effect on serum cholesterol concentration $(P<0.05)$ while BCS has a nonsignificant effect on serum cholesterol concentration $(P>0.05)$. The interaction effect of Parity $\times$ BCS $\times$ Week was also found nonsignificant $(P>0.05)$. Cows in parity 2 had significantly $(P<0.05)$ high glucose during week 6 and 7 .

The mean values of triglyceride concentration at different weeks after parturition are given in Table 3. The results showed that the BCS and postpartum intervals have a significant effect on serum triglyceride concentration $(P<0.05)$ while parity has nonsignificant effect on serum triglyceride concentration $(P>0.05)$. The interaction effect of Parity $\times$ BCS $\times$ Week was also found nonsignificant $(P>0.05)$. The serum triglyceride concentration in multiparous animals having BCS-2 during week 6 had significantly $(P<0.05)$ higher triglyceride.

The mean values of serum cortisol concentration at different weeks after parturition are given in Table 4. The results showed that parity, BCS, and postpartum intervals have a significant effect on serum cortisol concentration $(P<0.05)$. The interaction effect of Parity $\times$ BCS $\times$ Week was found nonsignificant $(P>0.05)$. Serum cortisol was significantly $(P<0.05)$ high in parity 1 during week 1 and 2 and significantly $(P<0.05)$ high in parity 2 during week 7 . This decreasing trend in serum cortisol concentration toward the commencement of the trial also clearly showed that the multiparous cows are comparatively chasing stress condition. 
Table 1 Mean \pm SE blood glucose $(\mathrm{mg} / \mathrm{dl})$ concentration at different postpartum weeks

\begin{tabular}{lccccc}
\hline P.P weeks & \multicolumn{1}{l}{ Parity-1 } & & \multicolumn{2}{l}{ Parity-2 } \\
\cline { 2 - 3 } \cline { 5 - 6 } & \multicolumn{1}{c}{ BCS-1 } & BCS-2 & & BCS-1 & BCS-2 \\
\hline Week-1 & $47.29^{\mathrm{e}} \pm 0.01$ & $50.17^{\mathrm{de}} \pm 0.02$ & & $51.89^{\mathrm{de}} \pm 0.01$ & $55.58^{\mathrm{de}} \pm 0.05$ \\
Week-2 & $52.24^{\mathrm{de}} \pm 0.01$ & $53.60^{\mathrm{de}} \pm 0.04$ & & $58.28^{\mathrm{cd}} \pm 0.04$ & $60.80^{\mathrm{c}} \pm 0.04$ \\
Week-3 & $56.12^{\mathrm{d}} \pm 0.04$ & $58.46^{\mathrm{cd}} \pm 0.05$ & & $62.70^{\mathrm{bc}} \pm 0.02$ & $65.67^{\mathrm{bc}} \pm 0.02$ \\
Week-4 & $55.22^{\mathrm{de}} \pm 0.04$ & $60.98^{\mathrm{c}} \pm 0.02$ & & $69.54^{\mathrm{b}} \pm 0.03$ & $72.78^{\mathrm{ab}} \pm 0.01$ \\
Week-5 & $58.04^{\mathrm{cd}} \pm 0.03$ & $60.14^{\mathrm{c}} \pm 0.02$ & & $67.28^{\mathrm{bc}} \pm 0.02$ & $72.38^{\mathrm{ab}} \pm 0.03$ \\
Week-6 & $65.21^{\mathrm{bc}} \pm 0.05$ & $66.21^{\mathrm{bc}} \pm 0.04$ & & $76.75^{\mathrm{ab}} \pm 0.04$ & $79.37^{\mathrm{ab}} \pm 0.01$ \\
Week-7 & $72.15^{\mathrm{ab}} \pm 0.03$ & $71.52^{\mathrm{ab}} \pm 0.02$ & & $84.59^{\mathrm{a}} \pm 0.01$ & $85.76^{\mathrm{a}} \pm 0.03$ \\
$P$-Value & Parity $=0.000, \mathrm{BCS}=0.041$, Week $=0.000$, Parity*BCS*Week $=0.998$ \\
\hline
\end{tabular}

Values with different superscripts differ significantly $(\mathrm{P}<0.05)$

$P P$ postpartum, Parity- 1 primiparous, Parity-2 multiparous, $B C S-1$ body condition score up to 3 and $B C S-2$ body condition score above 3

\begin{tabular}{|c|c|c|c|c|}
\hline \multirow[t]{2}{*}{ P.P weeks } & \multicolumn{2}{|l|}{ Parity-1 } & \multicolumn{2}{|l|}{ Parity-2 } \\
\hline & BCS-1 & BCS-2 & BCS-1 & BCS-2 \\
\hline Week-1 & $150.50^{\mathrm{ef}} \pm 0.06$ & $151.06^{\mathrm{ef}} \pm 0.01$ & $163.32^{\mathrm{d}} \pm 0.04$ & $165.07^{\mathrm{cd}} \pm 0.03$ \\
\hline Week-2 & $155.02^{\mathrm{e}} \pm 0.02$ & $155.15^{\mathrm{e}} \pm 0.03$ & $168.08^{\mathrm{c}} \pm 0.02$ & $171.40^{\mathrm{bc}} \pm 0.01$ \\
\hline Week-3 & $160.33^{\mathrm{de}} \pm 0.03$ & $159.47^{\mathrm{de}} \pm 0.03$ & $172.77^{\mathrm{bc}} \pm 0.01$ & $178.77^{\mathrm{b}} \pm 0.04$ \\
\hline Week-4 & $169.15^{\mathrm{c}} \pm 0.02$ & $165.89^{\mathrm{cd}} \pm 0.02$ & $181.91^{\mathrm{ab}} \pm 0.01$ & $182.57^{\mathrm{ab}} \pm 0.04$ \\
\hline Week-5 & $164.49^{\mathrm{cd}} \pm 0.01$ & $162.93^{\mathrm{d}} \pm 0.04$ & $179.07^{\mathrm{b}} \pm 0.04$ & $181.26^{\mathrm{ab}} \pm 0.02$ \\
\hline Week-6 & $171.66^{\mathrm{bc}} \pm 0.04$ & $168.88^{\mathrm{c}} \pm 0.02$ & $188.88^{\mathrm{a}} \pm 0.02$ & $189.29^{\mathrm{a}} \pm 0.01$ \\
\hline Week-7 & $180.30^{\mathrm{b}} \pm 0.04$ & $177.17^{\mathrm{b}} \pm 0.03$ & $199.51^{\mathrm{a}} \pm 0.01$ & $200.52^{\mathrm{a}} \pm 0.05$ \\
\hline$P$-Value & \multicolumn{4}{|c|}{ Parity $=0.000, \mathrm{BCS}=0.888$, Week $=0.000$, Parity $* \mathrm{BCS} *$ Week $=1.000$} \\
\hline
\end{tabular}

Values with different superscripts in a column differ significantly $(P<0.05)$

$P P$ postpartum, Parity- 1 primiparous, Parity- 2 multiparous, $B C S-1$ body condition score up to 3 and $B C S-2$ body condition score above 3

\begin{tabular}{lccccr}
\hline P.P weeks & \multicolumn{1}{l}{ Parity-1 } & & \multicolumn{2}{l}{ Parity-2 } \\
\cline { 2 - 3 } \cline { 5 - 6 } & \multicolumn{1}{c}{ BCS-1 } & BCS-2 & & BCS-1 & BCS-2 \\
\hline Week-1 & $11.79^{\mathrm{d}} \pm 0.04$ & $9.81^{\mathrm{e}} \pm 0.02$ & & $12.52^{\mathrm{cd}} \pm 0.02$ & $12.74^{\mathrm{cd}} \pm 0.05$ \\
Week-2 & $10.91^{\mathrm{de}} \pm 0.01$ & $10.39^{\mathrm{de}} \pm 0.01$ & & $12.44^{\mathrm{cd}} \pm 0.01$ & $14.79^{\mathrm{b}} \pm 0.05$ \\
Week-3 & $14.42^{\mathrm{b}} \pm 0.06$ & $12.96^{\mathrm{cd}} \pm 0.05$ & & $10.03^{\mathrm{de}} \pm 0.04$ & $13.84^{\mathrm{bc}} \pm 0.01$ \\
Week-4 & $16.70^{\mathrm{ab}} \pm 0.02$ & $14.06^{\mathrm{bc}} \pm 0.05$ & & $12.89^{\mathrm{cd}} \pm 0.01$ & $13.76^{\mathrm{bc}} \pm 0.02$ \\
Week-5 & $15.60^{\mathrm{ab}} \pm 0.01$ & $16.70^{\mathrm{ab}} \pm 0.04$ & & $15.16^{\mathrm{b}} \pm 0.03$ & $17.58^{\mathrm{ab}} \pm 0.03$ \\
Week-6 & $14.06^{\mathrm{bc}} \pm 0.03$ & $17.06^{\mathrm{ab}} \pm 0.01$ & & $16.26^{\mathrm{ab}} \pm 0.02$ & $18.45^{\mathrm{a}} \pm 0.04$ \\
Week-7 & $13.91^{\mathrm{bc}} \pm 0.05$ & $13.49^{\mathrm{c}} \pm 0.02$ & & $13.21^{\mathrm{cd}} \pm 0.04$ & $15.19^{\mathrm{b}} \pm 0.01$ \\
$P$-Value & Parity $=0.214, \mathrm{BCS}=0.055$, Week $=0.000$, Parity*BCS*Week $=0.578$
\end{tabular}

Values with different superscripts differ significantly $(P<0.05)$

$P . P$ postpartum, Parity- 1 primiparous, Parity- 2 multiparous, $B C S-1$ body condition score up to 3 and $B C S$ 2 body condition score above 3
The mean values of serum progesterone concentration at different weeks after parturition are given in Table 5. The results showed that parity, BCS, and postpartum intervals have a significant effect on serum progesterone concentration
$(P<0.05)$. The interaction effect of Parity $\times$ BCS $\times$ Week was also found significant $(P<0.05)$. Serum progesterone was significantly $(P<0.05)$ higher in cows during week 7 in parity 2 having BCS-2. 
Table 4 Mean \pm SE blood cortisol $(\mu \mathrm{g} / \mathrm{dl})$ concentration at different postpartum weeks

\begin{tabular}{lccccc}
\hline P.P weeks & \multicolumn{1}{l}{ Parity-1 } & & \multicolumn{2}{l}{ Parity-2 } \\
\cline { 2 - 3 } \cline { 5 - 6 } & BCS-1 & BCS-2 & & BCS-1 & BCS-2 \\
\hline Week-1 & $5.35^{\mathrm{a}} \pm 0.02$ & $4.77^{\mathrm{ab}} \pm 0.02$ & & $2.33^{\mathrm{d}} \pm 0.04$ & $1.82^{\mathrm{de}} \pm 0.03$ \\
Week-2 & $5.24^{\mathrm{a}} \pm 0.02$ & $4.59^{\mathrm{bc}} \pm 0.03$ & & $2.24^{\mathrm{d}} \pm 0.04$ & $1.74^{\mathrm{de}} \pm 0.04$ \\
Week-3 & $4.74^{\mathrm{ab}} \pm 0.04$ & $4.02^{\mathrm{c}} \pm 0.01$ & & $2.07^{\mathrm{d}} \pm 0.05$ & $1.57^{\mathrm{de}} \pm 0.03$ \\
Week-4 & $4.50^{\mathrm{bc}} \pm 0.01$ & $3.71^{\mathrm{cd}} \pm 0.02$ & & $1.87^{\mathrm{de}} \pm 0.02$ & $1.45^{\mathrm{e}} \pm 0.01$ \\
Week-5 & $4.62^{\mathrm{b}} \pm 0.02$ & $3.92^{\mathrm{cd}} \pm 0.03$ & & $1.57^{\mathrm{de}} \pm 0.01$ & $1.12^{\mathrm{e}} \pm 0.02$ \\
Week-6 & $4.08^{\mathrm{c}} \pm 0.01$ & $3.55^{\mathrm{cd}} \pm 0.04$ & & $1.32^{\mathrm{e}} \pm 0.04$ & $1.16^{\mathrm{e}} \pm 0.03$ \\
Week-7 & $3.56^{\mathrm{cd}} \pm 0.03$ & $3.09^{\mathrm{cd}} \pm 0.05$ & & $0.55^{\mathrm{f}} \pm 0.01$ & $0.42^{\mathrm{f}} \pm 0.01$ \\
$P$-Value & Parity $=0.000, \mathrm{BCS}=0.000$, Week $=0.000$, Parity*BCS*Week $=0.996$ \\
\hline
\end{tabular}

Values with different superscripts differ significantly $(P<0.05)$

$P . P$ postpartum, Parity- 1 primiparous, Parity-2 multiparous, $B C S-1$ body condition score up to 3 and $B C S$ 2 body condition score above 3

\begin{tabular}{lccccc}
\hline P.P weeks & Parity-1 & & \multicolumn{2}{l}{ Parity-2 } \\
\cline { 2 - 3 } \cline { 5 - 6 } & BCS-1 & BCS-2 & & BCS-1 & BCS-2 \\
\hline Week-1 & $0.76^{\mathrm{e}} \pm 0.01$ & $0.74^{\mathrm{e}} \pm 0.02$ & & $0.87^{\mathrm{d}} \pm 0.01$ & $0.88^{\mathrm{cd}} \pm 0.01$ \\
Week-2 & $0.79^{\mathrm{e}} \pm 0.01$ & $0.75^{\mathrm{e}} \pm 0.02$ & & $0.91^{\mathrm{c}} \pm 0.02$ & $0.90^{\mathrm{cd}} \pm 0.01$ \\
Week-3 & $0.84^{\mathrm{d}} \pm 0.02$ & $0.80^{\mathrm{de}} \pm 0.03$ & & $0.94^{\mathrm{c}} \pm 0.02$ & $0.92^{\mathrm{c}} \pm 0.01$ \\
Week-4 & $0.89^{\mathrm{cd}} \pm 0.01$ & $0.85^{\mathrm{d}} \pm 0.01$ & & $0.97^{\mathrm{bc}} \pm 0.01$ & $0.96^{\mathrm{bc}} \pm 0.02$ \\
Week-5 & $0.93^{\mathrm{c}} \pm 0.01$ & $0.90^{\mathrm{cd}} \pm 0.01$ & & $1.00^{\mathrm{bc}} \pm 0.06$ & $1.02^{\mathrm{bc}} \pm 0.02$ \\
Week-6 & $0.96^{\mathrm{bc}} \pm 0.03$ & $0.90^{\mathrm{cd}} \pm 0.02$ & & $1.12^{\mathrm{b}} \pm 0.02$ & $1.15^{\mathrm{b}} \pm 0.01$ \\
Week-7 & $0.98^{\mathrm{bc}} \pm 0.05$ & $0.96^{\mathrm{bc}} \pm 0.06$ & & $1.17^{\mathrm{b}} \pm 0.04$ & $1.39^{\mathrm{a}} \pm 0.04$ \\
$P$-Value & Parity $=0.000, \mathrm{BCS}=0.004$, Week $=0.000$, Parity*BCS*Week $=0.011$ \\
\hline
\end{tabular}

Values with different superscripts differ significantly $(P<0.05)$

$P . P$ postpartum, Parity- 1 primiparous, Parity- 2 multiparous, $B C S-1$ body condition score up to 3 and $B C S$ 2 body condition score above 3

\section{Discussion}

In the present study, glucose concentration increased with an increasing postpartum period. Moreover, multiparous cows showed a higher glucose profile at the end of the study period suggesting that multiparous cows are comparatively resistant to postpartum stress condition. The findings of many authors [13, 14] suggest that normal blood levels of various biochemical constituents are indispensable for normal function of various systems of the body including the reproductive system. The data showed that the increasing trend in serum glucose during the postpartum period increased the probability of first ovulation after calving in lactating dairy cows, because glucose certainly provides energy regarding resumption of reproductive function [2]. Theera [15] revealed that postpartum glucose level was greater in normal cycling dairy animals as compared to non-cycling because glucose may maintain the homeostatic process of the body, furthermore, when its concentration in the blood increases the stress may reduce.
Block et al. [1] reported detrimental effect of undernutrition and low blood glucose concentrations on postpartum cyclicity of dairy cows which is a strong argument for the present study.

In our study, the parity and postpartum intervals have a significant effect on serum cholesterol concentration. The serum cholesterol concentration is comparatively higher in multiparous cows. The serum cholesterol concentration was found to steadily increase after parturition. Cholesterol gradually increases after calving reflecting fat mobilization that occurs during this time. However, average cholesterol concentrations between weeks 5 and 6 were comparatively less in cyclic cows. Jeong et al. [4] reported that non-cyclic cows had lower total cholesterol than the cyclic cows. Cholesterol is a precursor of ovarian steroidogenesis. The increase in progesterone concentration was due to decrease in cortisol level and more availability of cholesterol [1]. The result of the present study is relevant to the findings of Chalmeh et al. [16] who argued that body fat does not have a direct causal role in regulating reproductive cyclicity. 
Increased triglyceride is due to the mobilization of fatty acids from adipose tissue that occurs in times of NEB or stress. The liver always takes up a constant proportion of fat and oxidizes it in accordance with the need for ATP, the rest are esterified to triglycerides creating a disposal sink and a condition known as fatty liver. Primiparous cows are immature and present unbalanced endocrine metabolic profiles compared to multiparous. Cholesterol and triglycerides in our study showed an increasing trend during the postpartum period. The results indicated that high-yielding cows are more prone to NEB, therefore, the loss in body weight and marked decrease in BCS during postpartum period are associated with delay in ovarian resumption. The higher cholesterol and triglyceride in the multiparous cows with higher BCS is due to the fact that the overconditioned cows exhibit decreased appetite and develop more NEB, ultimately undergo pronounced mobilization of fat and probably accumulate more triglyceride and cholesterol [9].

Cortisol which is produced by the adrenal glands is the major stress hormone [17]. The serum cortisol concentration decreases during postpartum weeks. In addition, the stress level is more severe in the primiparous cows than multiparous. The reduced cortisol level with the increasing period may be the adaptability potential of the cows. Furthermore, the higher level of cortisol in the primiparous cows indicates that these cows experience more stress than multiparous cows during the postpartum period.

In the present study, serum progesterone is increasing with the increasing postpartum period in both types of cows, however, the increase was higher in multiparous cows during week 7. A close association between glucose availability, serum progesterone profile, and reproductive function has been previously reported [1]. In our study, multiparous cows with higher BCS had higher progesterone concentration at the end of the 7th week. In the study of $[9,17]$, the cows with lower BCS resumed ovarian cyclicity later than the cows with higher BCS. Poor BCS is associated with NEB which adversely affects the development of ovarian follicles leading to lower progesterone concentration [9]. The results of the present revealed that the multiparous cows are better in maintaining the postpartum stress and resumption of ovarian cyclicity as compared to primiparous cows.

Acknowledgment The authors are thankful to the Higher Education Commission (HEC) of Pakistan for funding this work through indigenous Ph.D. scholarship.

\section{References}

1. Block SS, Butler WR, Ehrhardt RA, Bell AW, Van Amburgh ME, Boisclair YR (2001) Decreased concentration of plasma leptin in periparturient dairy cows is caused by negative energy balance. J Endocrinol 171:339-348

2. Royal M, Mann GE, Flint PE (2000) Strategies for reversing the trend towards sub fertility in dairy cattle. Vet J 160:53-60

3. Butler WR (2003) Energy balance relationships with follicular development, ovulation and fertility in post-partum dairy cows. Livest Prod Sci 83:211-218

4. Jeong JK, Choi IS, Kang HG, Hur TY, Jung YH, Kim IH (2015) Relationship between serum metabolites, body condition, periand post-partum health and resumption of post-partum cyclicity in dairy cows. Livest Sci 181:31-37

5. Taylor VJ, Beever DE, Bryant MJ, Wathes DC (2003) Metabolic profiles and progesterone cycles in first lactation dairy cows. Theriogenology 59:1661-1677

6. Mojtaba CR, Thatcher WW, Clark JH (2012) Relation between ovarian activity and energy status during the early post-partum period of high producing dairy cows. J Dairy Sci 73:938-947

7. Shin E, Jeong J, Choi I, Kang H, Hur T, Jung Y, Kim I (2015) Relationships among ketosis, serum metabolites, body condition, and reproductive outcomes in dairy cows. Theriogenology $84: 252-260$

8. Opsomer G, Gröhn YT, Hertl J, Coryn M, Deluyker H, de Kruif A (2000) Risk factors for post partum ovarian dysfunction in high producing dairy cows in Belgium: a field study. Theriogenology 53:841-857

9. Shrestha HK, Nakao T, Suzuki T, Akita M, Higaki T (2005) Relationships between body condition score, body weight, and some nutritional parameters in plasma and resumption of ovarian cyclicity post-partum during pre-service period in high-producing dairy cows in a subtropical region in Japan. Theriogenology 64:855-866

10. Thatcher WW, Wilcox CJ (2004) Post-partum estrus as an indicator of reproductive status in the dairy cow. J Dairy Sci $56: 608-612$

11. Looper ML, Lents CA, Wettemann RP (2003) Body condition at parturition and post-partum weight changes do not influence the incidence of short lived corpora lutea. In post-partum dairy cows. J Dairy Sci 81:2390

12. Carlos AR (2004) Managing the post-partum cow to maximize pregnancy rates, 10 proceedings Florida Dairy Reproduction cycles In first lactation dairy cows. Theriogenology 59:1661-1677

13. El-Azab MA, Badr A, El-Sadawy G, Shawki Borkat TM (1993) Some biochemical changes in relation to post-partum ovarian activity in dairy cows. Indian J Anim Sci 63:1244-1247

14. Balakrishnan V, Balagopal R (1994) Serum calcium, phosphorous, magnesium, copper and zinc levels in regular breeding buffaloes. Indian Vet J 71:23-25

15. Theera R (2010) A field study on negative energy balance in periparturient dairy cows kept in small-holder farms: effect on milk production and reproduction. Thai J Agric Res 5:3157-3163

16. Chalmeh A, Hajimohammadi A, Nazifi S (2015) Endocrine and metabolic responses of high producing Holstein dairy cows to glucose tolerance test based on the stage of lactation. Livest Sci 181:179-186

17. Shrestha HK, Nakao T, Higaki T, Suzuki T, Akita M (2004) Resumption of post-partum ovarian cyclicity in high-producing Holstein cows. Theriogenology 61:637-649 